\title{
ANOMALOUS COLOURATION OF A STARRY WEEVER, TRACHINUS RADIATUS (ACTINOPTERYGII: PERCIFORMES: TRACHINIDAE), FROM THE ADRIATIC SEA
}

\author{
Nika STAGLIČIĆ, Branko DRAGIČEVIĆ*, Iva ŽUŽUL, and Tanja ŠEGVIĆ-BUBIĆ \\ Institute of Oceanography and Fisheries, Split, Croatia
}

\begin{abstract}
Stagličić N., Dragičević B., Žužul I., Šegvić-Bubić T. 2019. Anomalous colouration of a starry weever, Trachinus radiatus (Actinopterygii: Perciformes: Trachinidae), from the Adriatic Sea. Acta Ichthyol. Piscat. 49 (2): 177-180.
\end{abstract}

\begin{abstract}
The record of abnormally pigmented starry weever, Trachinus radiatus Cuvier, 1829, is described. The specimen was caught in Nature Park Lastovo archipelago, eastern Adriatic Sea, and displayed an overall lack of usual dark brown pigmentation. The skin was marked by a predominance of yellow to red pigments corresponding with a rare colour anomaly condition of xanthochromism. Due to the unusual appearance of the specimen, we used molecular methods for proper identification of the species. This seems to be the first documented record of xanthochromism in the family Trachinidae.
\end{abstract}

Keywords: xanthochromism, abnormal pigmentation, abnormal colouration, Adriatic Sea, Trachinus, Nature Park Lastovo

\section{INTRODUCTION}

Fish display a remarkable variety of body colours and patterns that differ both within and between species (Fujii 1993, Mills and Patterson 2009). Colouration and patterning are traits with high ecological significance and serve diverse functions in that sense, e.g., predation avoidance, mate recognition and choice, camouflage, photoprotection, visual communication, or shoaling preference (Mills and Patterson 2009, Leclercq et al. 2010, Nüsslein-Volhard and Singh 2017).

Pigmentation patterns develop as a complex combination of local (e.g., cellular interactions between individual chromatophores) and global (e.g., environmental, nutritional) signals (Venizelos and Benetti 1999, Mills and Patterson 2009). Disturbances of normal developmental pathways for body colour and patterning result in malpigmentations - uncharacteristic pigmentation for certain fish species (Colman 1972, Bolker et al. 2005). Scientific reports of abnormally pigmented fish usually classify those pigmentations into few broad categories such are ambicolouration, albinism, and xanthochromism (Colman 1972, Venizelos and Benetti 1999, Bolker et al. 2005, Jawad and Al-Kharusi 2013, Wishkerman et al. 2016). Xanthochromism is a colour abnormality in which the melanophores are missing, but other pigments are present. Lack of melanophores allows the underlying xanthophores to be unmasked, commonly producing a golden-orange colour. It has been suggested by Angus and Blanchard (1991) that xanthophores may even be overproduced in the absence of melanophores or other pigment cells. Aberrant colour and pigment patterns are particularly common in aquaculture, where they create a problem of reduced marketability (Leclercq et al. 2010, Wishkerman et al. 2016). Compared to rearing conditions, cases of abnormal pigmentation are much rarer in wild populations (Venizelos and Benetti 1999, Wishkerman et al. 2016), and especially so for fish groups other than flatfish (Colman 1972, Jawad and Al-Kharusi 2013 and references therein).

Starry weever, Trachinus radiatus Cuvier, 1829, is a coastal, marine species, found on sand and muddy bottoms on the continental shelf from the shoreline to a depth of about $150 \mathrm{~m}$. It is distributed in eastern Atlantic, from Portugal to Angola, and probably further south and is widespread in the Mediterranean, with the exception of the Black Sea (Jardas 1996). It can grow up to $50 \mathrm{~cm}$ in length (Froese and Pauly 2019), while Jardas (1996) reports a maximum observed length of $40 \mathrm{~cm}$ for the Adriatic Sea. Although body colouration pattern in this species can vary, it is always characterized by the patterns consisting of dark brown colouration.

In this paper, we present the first record of abnormally pigmented starry weever, Trachinus radiatus.

\section{MATERIALS AND METHODS}

The specimen of Trachinus radiatus was caught in November 2016 by bottom longline set over a sandy bottom at a depth of $70 \mathrm{~m}$ in the area of the Nature Park Lastovo (Lastovo archipelago) (Fig. 1). To confirm the 
specimen as $T$. radiatus, distinguishing morphological criteria described in the identification key for Adriatic fish species by Jardas (1996) were used.

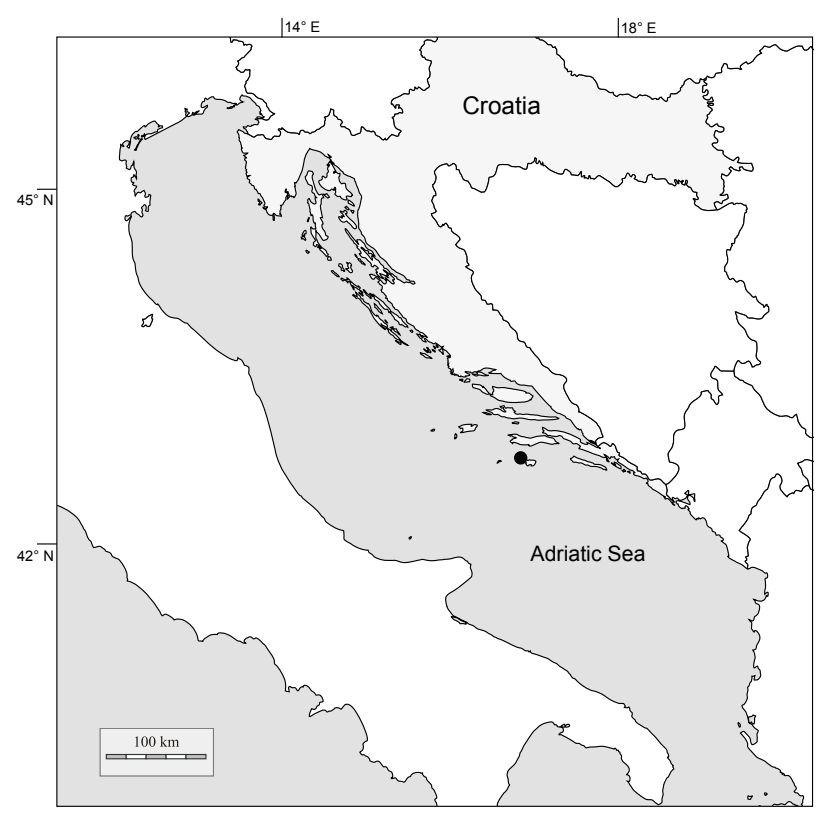

Fig. 1. Map of the region and location where aberrantly coloured starry weever, Trachinus radiatus, specimen was caught (black dot)

To verify the validity of the morphological approach and gain an explicit species identification, a pectoral fin clip was also collected, preserved in 100\% ethanol, and submitted for genetic analysis. The specimen was deposited in the ichthyological collection at the Institute of Oceanography and Fisheries (TR-XC-01).

DNA extraction and amplification. To genetically identify the specimen, DNA was extracted from a piece of fin tissue using the DNeasy 96 Tissue Kit (Qiagen) following the manufacturer's protocol. A partial fragment of the mitochondrial cytochrome $\mathrm{c}$ oxidase subunit I (COI) was amplified following Ward et al. 2005. Products sequencing were performed by Macrogen Inc. (Seoul, Korea) on an ABI 3730 automatic sequencer. BLASTn (NCBI, available online) was used for sequence identification. Sequence alignment was carried out using the ClustalW tool, Mega v6 software (Tamura et al. 2013). The obtained COI sequence was deposited in GenBank (Accession Number: MK684404).

\section{RESULTS}

The specimen was determined as a representative of Trachinus radiatus based on morphological and meristic characters provided by Jardas (1996) but also based on genetic analysis. Besides the colour and pattern, there were no other noticeable morphological divergences. The reported specimen was an $1162 \mathrm{~g}$ mature female that measured $47.1 \mathrm{~cm}$ in total length. The state of gonads indicated recent spawning event which corresponds to the known spawning period of $T$. radiatus from late autumn to the beginning of winter. The total length of the specimen exceeds the previously reported maximal length of $40 \mathrm{~cm}$ for the Adriatic (Jardas 1996) by almost 18 percentage points.

Genetic analysis unequivocally identified the specimen as Trachinus radiatus. Namely, a 645 bp long mtDNA COI fragment of the studied specimen was nearly identical to the Mediterranean sequences available in GenBank: an uncorrected p-distance of 0.2 percentage points was scored between our sample and the three Mediterranean haplotypes (KJ709937.1, KJ709939.1, KJ709938.1) reported by Landi et al. (2014).

The colouration of the specimen was aberrant in such a way that the skin was almost completely devoid of usual dark brown pigmentation (Fig. 2A). The melanin pigment was absent throughout the body except from two small, irregular patches on the head-one over the radiating bony crests and the other above the upper jaw (Fig. 2B). Red and yellow pigments were unaffected and body colour could be described as bright golden yellow mottled with numerous tiny orange to reddish spots. Spots were present to second dorsal and caudal fin, but the specimen lacked the usual darker terminal bands on either of those fins. The first dorsal fin was also deficient in melanin and instead of the usual black colour, it was uniformly orange. Regarding the other aberrant pigmentation pattern, characteristic leopard-like or vermicular blotches along the sides of the body were also absent.

\section{DISCUSSION}

To our knowledge, this is the first report of abnormal pigmentation in wild starry weever, Trachinus radiatus. The described colour and pigmentation pattern abnormalities indicate to the condition of xanthochromism which is characterised by a loss or severe reduction of darker pigments allowing the remaining non-melanin pigments to be unusually dominant (Pattengill-Semmens 1999). Typically, this rare skin condition results in golden to orange appearance as seen in the starry weever specimen.

Previous reports of xanthocroic fish include a wide taxonomic array of species both marine and freshwater. For illustration, this condition has been reported for marine fish families such as Carangidae (see Jawad and Ibrahim 2018), Pomacentridae (see Palacios-Salgado and RojasHerrera 2012), Serranidae (see Moe 1963, Schwartz 1978, Smith and Bullock 1979, Nemtzov et al. 1993, Jawad and Al-Kharusi 2013, Jawad and Ibrahim 2018), Sebastidae (see Davenport 1966, Ueber 1989, Cripe 1998), and few families in the order Pleuronectiformes (see Dawson 1969, Moore and Posey 1974, Akyol and Şen 2012, Ulutürk et al. 2015).

The majority of marine records originated from the Atlantic and fewer of them from Pacific regions. Geographically the closest reports of other xanthochroic cases are from Aegean Sea by Akyol and Şen (2012) who described a specimen of common sole, Solea solea, with partially ambicolorated, xanthochroistic, and albinistic features, while Ulutürk et al. (2015) also found all three different types of colour anomalies on a single specimen of the wedge sole, Dicologlossa cuneata 


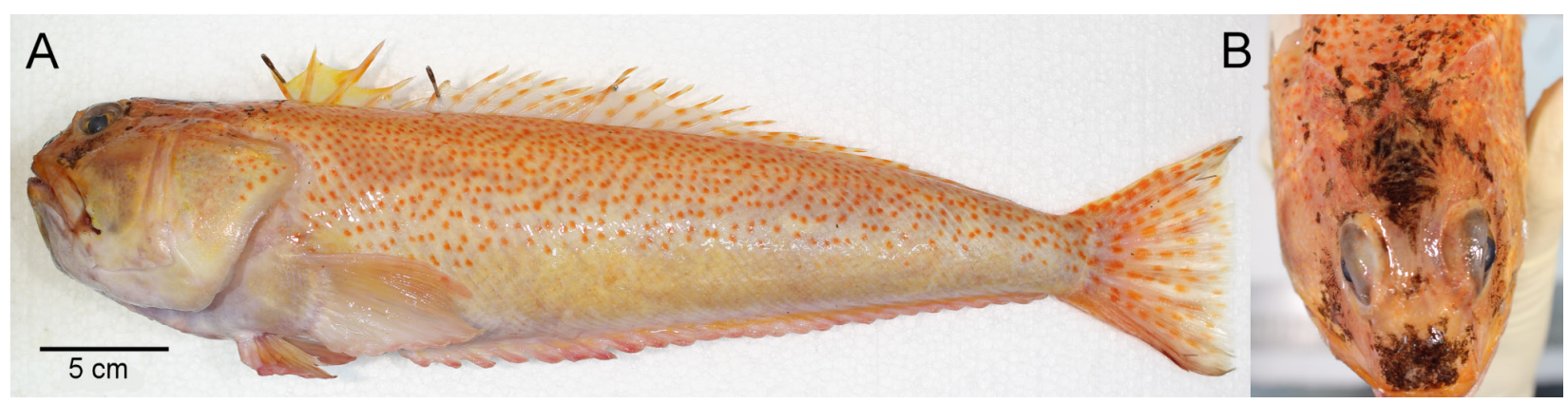

Fig. 2. Aberrantly coloured starry weever: whole body (A) head region with the only dark patches of skin pigmentation (B)

(Moreau, 1881). To date, no case of malpigmentation has been documented for a species of the family Trachinidae. Although the phenomenon of xanthochroic pigmentary anomaly has been reported for a number of fish taxa, most often it was on a single specimen or with low population frequencies (Carson 2011) so it is considered particularly rare. The rarity of xanthic malpigmentations is generally assumed to emanate from increased conspicuousness of such specimens and their consequent elevated predation risks (Carson 2011 and references therein). However, the fact that our specimen was an adult able to spawn and generally in a good and apparently healthy condition, allows us to presume that its loss of usual pigmentation did not affect its ability to survive. Following this presumption and considering traces of brown pigment still visible on the head area, it is also possible that the loss of pigmentation occurred later in its life due to an unknown cause. The aetiology of this particular malpigmentation is the least studied and understood when compared to insights on possible causes of albinism and ambicolouration (Jawad and AlKharusi 2013). Occurrence of aberrant colouration in fishes can stem from a variety of reasons and studies up to now have implicated genetic mutations (Dunham and Childers 1980), environmental factors (Vanizelos and Benetti 1999 and references therein), nutrition (Vanizelos and Benetti 1999 and references therein), neurological aspects (Vanizelos and Benetti 1999). Nüsslein-Volhard and Singh (2017) proposed that normal colour and pattern formation depends also on interactions between the different pigment cells. The aberrantly coloured starry weever reported here represents the first documented occurrence of xanthochromism for the family Trachinidae. Due to the general rarity of the phenomenon in wild fish populations, this new data broadens the knowledge of the phenotypic variability existing in starry weever populations.

\section{ACKNOWLEDGEMENTS}

The authors would like to thank the CSI Lastovo team-Klavdij Kogoj, Alen and Rosa Mujanović, who caught the fish and provided it for identification. This work has been supported in part by the Croatian Science Foundation in the frames of the project LEK-Fish-ResCRO, IP-2016-06-5251.

\section{REFERENCES}

Akyol O., Şen H. 2012. First record of abnormal pigmentation in a wild common sole, Solea solea L., from the Aegean Sea. Turkish Journal of Veterinary and Animal Sciences 36 (6): 727-729. DOI: 10.3906/ vet-1110-7

Angus R.A., Blanchard P.D. 1991. Genetic basis of the gold phenotype in sailfin mollies. Journal of Heredity 82 (5): 425-428. DOI: 10.1093/oxfordjournals.jhered. a111118

Bolker J.A., Hakala T.F., Quist J.E. 2005. Pigmentation development, defects, and patterning in summer flounder (Paralichthys dentatus). Zoology 108 (3): 183-193. DOI: 10.1016/j.zool.2005.05.001

Carson E.W. 2011. Low but stable frequency of xanthic phenotypes in a population of the twoline pupfish, Cyprinodon bifasciatus. American Midland Naturalist 166 (2): 462-466. DOI: 10.1674/0003-0031-166.2.462

Colman J.A. 1972. Abnormal pigmentation in the sand flounder (note). New Zealand Journal of Marine and Freshwater Research 6 (1-2): 208-213. DOI: 10.1080/00288330.1977.9515419

Cripe D. 1998. Occurrence of xanthic grass rockfish, Sebastes rastrelliger. California Fish and Game 84 (2): 100-101.

Davenport D. 1966. Colour variant of bocaccio (Sebastodes paucispinis) in British Columbia waters. Journal of the Fisheries Research Board of Canada 2 (12): 1981. DOI: $10.1139 /$ f66-186

Dawson C.E. 1969. Three unusual cases of abnormal coloration in northern Gulf of Mexico flatfishes. Transactions of the American Fisheries Society 98 (1): 106-108. DOI: 10.1577/1548-8659(1969)98[106:TUCOAC]2.0.CO;2

Dunham R.A., Childers W.F. 1980. Genetics and implications of the golden color morph in green sunfish. The Progressive Fish-Culturist 42 (3): 160-163. DOI: 10.1577/1548-8659(1980)42[160:GAIOTG]2.0.CO;2

Froese R., Pauly D. (eds.) 2019. FishBase. [Version 02/2019] http://www.fishbase.org

Fujii R. 1993. Cytophysiology of fish chromatophores. International Review of Cytology 143: 191-216, 216a, 216b, 217-255. DOI: 10.1016/S0074-7696(08)61876-8

Jardas I. 1996. Jadranska ihtiofauna. [Adriatic ichthyofauna.] Školska knjiga, Zagreb. [In Croatian.] 
Jawad L.A., Al-Kharusi L.H. 2013. A reported case of abnormal pigmentation in the epaulet grouper Epinephelus stoliczkae (Day, 1875) collected from the Sea of Oman. Anales de Biología 35: 41-44. DOI: 10.6018/analesbio.0.35.6

Jawad L.A., Ibrahim M. 2018. Partial xanthism and xanthic phenotype in two fish species from Jubail City, Arabian Gulf, Saudi Arabia. Cahiers de Biologie Marine 59 (1): 37-42. DOI: 10.21411/CBM.A.9F358FD8

Landi M., Dimech M., Arculeo M., Biondo G., Martins R., Carneiro M., Carvalho G.R., Lo Brutto S., Costa F.O. 2014. DNA barcoding for species assignment: The case of Mediterranean marine fishes. PLoS ONE 9 (9): e106135. DOI: 10.1371/journal.pone.0106135

Leclercq E., Taylor J., Migaud H. 2010. Morphological skin colour changes in teleosts. Fish and Fisheries 11 (2): 159-193. DOI: 10.1111/j.1467-2979.2009.00346.x

Moe M.A.jr. 1963. Partial albinism in a xanthic specimen of Epinephelus morio (Valenciennes) from the Gulf of Mexico. Copeia 1963 (4): 703. DOI: 10.2307/1440977

Mills M.G., Patterson L.B. 2009. Not just black and white: Pigment pattern development and evolution in vertebrates. Seminars in Cell and Developmental Biology 20 (1): 72-81. DOI: 10.1016/j. semcdb.2008.11.012

Moore C.J., Posey C.R.sr. 1974. Pigmentation and morphological abnormalities in the hogchoker, Trinectes maculatus (Pisces, Soleidae). Copeia 1974 (3): 660-670. DOI: 10.2307/1442679

Nemtzov S.C., Kajiura M., Lompart C.A. 1993. Diel color phase changes in the coney, Epinephelus fulvus (Teleostei, Serranidae). Copeia 1993 (3): 883-885. DOI: $10.2307 / 1447259$

Nüsslein-Volhard C., Singh A.P. 2017. How fish color their skin: A paradigm for development and evolution of adult patterns: Multipotency, plasticity, and cell competition regulate proliferation and spreading of pigment cells in zebrafish coloration. BioEssays 39 (3): 1600231. DOI: 10.1002/bies.201600231

Palacios-Salgado D.S., Rojas-Herrera A.A. 2012. Partial xanthism in a specimen of Acapulco major, Stegastes acapulcoensis (Teleostei: Pomacentridae), from the
Tropical Eastern Pacific. Pan-American Journal of Aquatic Sciences 7 (3): 175-177.

Pattengill-Semmens C.V. 1999. Occurrence of a unique color morph in the smooth trunkfish (Lactophrys triqueter L.) at the Flower Garden Banks and Stetson Bank, northwest Gulf of Mexico. Bulletin of Marine Science 65 (2): 587-591.

Tamura K., Stecher G., Peterson D., Filipski A., Kumar S. 2013. MEGA6: Molecular Evolutionary Genetics Analysis version 6.0. Molecular Biology and Evolution 30 (12): 2725-2729. DOI: 10.1093/molbev/ mst197

Schwartz F.J. 1978. Xanthochromism in Epinephelus drummondhayi (Pisces: Serranidae) caught off North Carolina. Northeast Gulf Science 2 (1): 62-64. DOI: 10.18785/negs.0201.06

Smith G.B., Bullock L.H. 1979. Xanthic specimens of the speckled hind, Epinephelus drummondhayi (Serranidae), from the eastern Gulf of Mexico. Florida Scientist 42 (4): 252-253.

Ueber E. 1989. Xanthic, gigantic, China rockfish. California Fish and Game 75 (1): 47-48.

Ulutürk E., Bayhan B., Filiz H., Deniz Acarli D., Irmak E. 2015. Abnormalities in the wedge sole Dicologlossa cuneata (Moreau, 1881) and black sea turbot Scophthalmus maeoticus (Pallas, 1814) from Turkish seas. Journal of Aquaculture Engineering and Fisheries Research 1 (2): 98-103. DOI: 10.3153/ JAEFR 15010

Venizelos A., Benetti D.D. 1999. Pigment abnormalities in flatfish. Aquaculture 176 (1): 181-188. DOI: 10.1016/S0044-8486(99)00060-5

Ward R.D., Zemlak T.S., Innes B.H., Last P.R., Hebert P.D.N. 2005. DNA barcoding Australia's fish species. Philosophical Transactions of the Royal Society B 360 (1462): 1847-1857. DOI: 10.1098/rstb.2005.1716

Wishkerman A., Boglino A., Darias M.J., Andree K.B., Estévez A., Gisbert E. 2016. Image analysisbased classification of pigmentation patterns in fish: A case study of pseudo-albinism in Senegalese sole. Aquaculture 464: 303-308. DOI: 10.1016/j. aquaculture.2016.06.040

Received: 27 June 2018

Accepted: 11 October 2018 Published electronically: 15 June 2019 